\title{
БУРЛУК - БУРЛУЧОК: ФОРМАЛЬНО НЕЗМІННІ ТА ГРАМАТИЧНО ПЕРЕОФОРМЛЕНІ ІМЕНА (У БАСЕЙНІ РІЧКИ ВЕЛИКИЙ БУРЛУК)
}

Ткаченко Є. М. Бурлук - Бурлучок: формально незмінні та граматично переоформлені імена (у басейні річки Великий Бурлук).

У роботі досліджено особливості взаємодії гідроніма Бурлук / Бурлучок та назв суміжних поселень із топонімною основою Бурлук-, проаналізовано основні структурні типи гідронімів і ойконімів, що стали результатом топонімічної метонімії, та охарактеризовано напрямки назвотворення із вихідними гідронімними лексемами.

Ключові слова: топонім, гідронім, ойконім, топонімна (гідронімна) лексема, топонімічна метонімія.

Ткаченко Е. Н. Бурлук - Бурлучек: формально неизменные и грамматически переоформленные имена (в бассейне реки Великий Бурлук).

В работе исследованы особенности взаимодействия гидронима Бурлук / Бурлучек и названий смежных населённых пунктов с топонимической основой Бурлук-; проанализированы основные структурные типы гидронимов и ойконимов, появившиеся в результате топонимической метонимии; охарактеризованы направления имятворчества с исходными гидронимными лексемами.

Ключевые слова: топоним, гидроним, ойконим, топонимическая (гидронимная) лексема, топонимическая метонимия.

Tkachenko Y. M. Burluk - Burluchok: formally unchanged and grammar reframed names (in the basin of Great Burluk river).

The characteristics of interaction of hydronyms Burluk / Burluchok and names of adjacent settlements of toponymic stem Burluk- are studied in the article, the main structural types of hydronyms and oikonyms which become the result of the toponymic metonymy are also analyzed, and the ways of making the names with the original hydronymic lexemes are characterized too.

Key words: toponym, hydronym, oikonym, toponymic (hydronymic) lexeme, toponymic metonymy.

(C) Є. М. Ткаченко, 2013. 
Територія колишньої Харківської губернії, як і сучасної Харківщини, належить до таких, де значну частину географічного простору займають річки, позначені давньотюркськими іменами. Тюркський топонімний шар відображено в назвах невеликих та середніх за протяжністю лінійних об'єктів, які мають незначну повноводність. Іноді такі водотоки продукують територіально обмежені річкові басейни, або окремі «жмутки» річок, із головним та прилеглими руслами. Безпосередня географічна локалізація річкових об'єктів сприяла тому, що топонімні лексеми, виділяючи суміжні географічні одиниці 3-поміж ряду інших, впливають один на одного і в подальшому зазнають морфологічної перебудови. 3 іншого боку, такі гідроніми від часу появи на берегах співвідносних річок ряду населених пунктів починають передавати свої назви цим поселенням. 3'являється ціла група топонімів, різних за структурою та семантикою, 3 індивідуальними твірними лексемами. Явище взаємодії гідронімів та ойконімів, або топонімічна метонімія, багаторазово висвітлювалося у працях Є. С. Отіна [6; 7; 8], аналізувалося також у статтях Л. Т. Масенко [2], Є. М. Черняхівської [12; 13], Н. Є. Михайличенко [3], у дисертації М. М. Юрківа [14] та ін.

Обрання об'єктом нашого дослідження топоніма Бурлук та його похідних зумовлене необхідністю прослідкувати особливості взаємодії топонімів різних класів, виявити структурні типи вихідних і похідних лексем, з'ясувати способи топонімотворення з вихідною лексемою бурлук.

Окрім Харківщини, назви з основою Бурлук відомі в інших країнах колишнього СРСР. Так, у Котовському районі Волгоградської області $\epsilon$ село Бурлук. У Північно-Казахстанській області Айиртауському районі (Республіка Казахстан) трапляється аж три населені пункти на річці Бурлук - Акан-Бурлук, Бурлук і Нижній Бурлук.

Наявна етимологія гідроніма Бурлук на апелятивному рівні має значення 'осад (від брудної води)', 'земля, непридатна для обробки' [Радлов 4, 2, ствб. 1661]. М. Фасмер виводить цю гідронімну лексему від турецького географічного апелятива borluk [Фасмер 1, с. 246] із подальшою асиміляцією голосного [о]. Схожа інтерпретація наявна в македонських діалектах, де трапляється лексема бърло́к - 'каламутна брудна вода' [Григорян 1975, с. 32]. Маловірогідно, що на апелятимвному рівні гідронім мав демінутивний відтінок із граматичним значенням множини, який трапляється в дослідженні В. В. Радлова - bÿрlӥчki 'рід невеликої гагри' [Радлов 4, 2, ствб. 1891-1892]. Є й інші припущення щодо семантики терміна - 'місиевість, де багато вовків', 'місия, у яких зазнали голоду' [ТСХ 1991, с. 69] тощо.

У топонімії північно-східної Харківщини наявні структурно-семантичні групи назв із спільною кореневою морфемою, що мають особливість утворювати власну систему споріднених назв, де гідроніми об'єднуються в окремі ряди разом із залежними ойконімами. Така система власних назв характеризується наявністю в кожній групі твірного гідроніма та похідних 
ойконімних лексем, що в окремих випадках є омонімічними до назв річок у результаті розщеплення топоніма. Перша така група складається з вихідного гідроніма Бурлук [АХН-1787; КБЧ, с. 71; ИСОХГ, с. 151; КСУГ-РА] (вар. Великий Бурлук [Р. ПГОНО, с. 255]) та ряду похідних утворень: Великий Бурлук, сл. [Хр Ввч, ИСОХЕ-4, с. 307; СМУВХГ, с. 96; ССОВХГ, с. 96; Хр Вбрл, ТКХО] (вар. Бурлук, сл. [Хр Ввч, ИСОХГ, с. 126; КСУГ-РА]) та Бурлук Великий, сл. [Хр Ввч, ХГ СНМ, с. 69]). Друга група географічних назв поєднує в собі твірний гідронім Середній Бурлук [Р. ПГОНО, с. 256] та похідну ойконімну лексему - Середній Бурлук (Картавий), сл. [Хр Ввч, КВУ-2]. Третя група представлена твірним гідронімом Сухий Бурлук [КВУ2 ; Р. ПГОНО, с. 256] із його демінутивним варіантом Сухий Бурлучок [АХН1787; ОХН, с. 99]. Узаємозв'язані ойконімні моделі з вихідним гідронімом Сухий Бурлук відсутні. Гіпотетичним є етимологічний зв'язок такої назви, що не має аугментативного значення, з ії демінутивним відповідником Бурлучок [ИСОХГ, с. 133]. Саме друга (суфіксальна) назва того самого річкового об'єкта завдяки внутрішній омонімії залишила свій відбиток на ойконімній реалемі у вигляді лексеми Бурлучок, д. [Хр Ввч, ХГ СНМ, с. 67]).

У топонімному словотвірному ряді назви річки Сухий Бурлук зафіксована тільки першофіксація Нове Бурлуцьке, с. [Хр Пчн, ЗПХО, с. 59] (вар. Новобурлуцьке, с. [Хр Ввч, Р. ПГОНО, с. 256; ХГ СНМ, с. 64;]) на відміну від Бурлуцьького, с. [Xp I3, ОХН, с. 166], яке згодом втратило словозміну прикметника i перетворилося 3 композита в ойконімне словосполучення Новий Бурлук, с. [Хр Чг, АТУ-87, с. 283; Хр Пчн, АТП-46, c. 611]. На цьому етапі перша частина двослівної назви новий вказує, що поселення виникло пізніше Великого Бурлука, який стосовно Нового Бурлука є старим, але оскільки він уже має гідронімний епітет великий, то означення, що вказує на вікові особливості об'єкта, за ним не закріпилося. Демінутивність прикметника сухий ще більше підкреслюється антонімами сухий - мокрий, які «при загальній визначальній частині складеного топоніма нерідко виражають той же тип відношень, що й нульовий топоформант та демінутивний суфікс в однокореневих найменуваннях головної річки і притоки» [Отин 1976, с. 19]. Отже, гідронім Сухий Бурлук співвідноситься з назвою річки Мокрий Бурлучек [ІСУ, с. 17; ОХН, с. 26, 29, с. 99] (вар. Бурлук / Великий Бурлук]). Гідронім Бурлук (Великий Бурлук) є аугментативом до гідроніма Мокрий Бурлучок. Відповідно, гідронім Сухий Бурлук, що семантично відповідає назві річки Бурлучок, разом із нею утворюють демінутивний словотвірний ряд. Заміна означення великий на мокрий підтверджується детальним аналізом виявлених топонімних фактів, які дають підставу вважати сучасну форму Великий Бурлук звичайним варіантом вихідного Бурлук (Мокрий Бурлук). У «Книге Большому Чертежу» знаходимо: «...ниже Гнилицы, с версту, с Ногайской стороны, пала в Донец речка Бурлучек (тобто Сухий Бурлук - прим. наша - С.Т.). А ниже ๑) Є. М. Ткаченко, 2013. 
Бурлучека, с версту, с Ногайской стороны, пала в Донец речка Бурлук от Изюмской дороги» [КБЧ, с. 71].

В «Описах Харківського намісництва кінця XVIII ст.» наводиться ряд річок, що впадають у Сіверський Донець з лівого боку: Корінь, Вовча, Повна, Хотімля, Гнилиия, Мокрий Бурлучок та ін. [ОХН, с. 126]. Певної згадки про річку Бурлук (Великий Бурлук) нема. Наші припущення також підтверджуються й тією обставиною, що довжина річки Мокрий Бурлучок у деяких пам'ятках XVIII ст. дорівнює сорока верстам і збігається 3 довжиною річки Великий Бурлук на сучасних топографічних картах досліджуваного регіону (тут іiі довжина дорівнює приблизно 75 км). Аналогічна ситуація з переліком приток Сіверського Дінця трапляється в «Историко-статистических описаниях Харьковской губернии», тільки в цих описах, крім річки Бурлучок, яка «в Сіверський Донець впадає $з$ лівого боку» [ИСОХГ, с. 133], згадується ще й річка Бурлук [Там само, с. 151].

В ойконімах - назвах слобід - Середній Бурлук (Бурлучок Середній, Середній Бурлучок) мотивуючою є ознака 'локалізований у середній частині течії річки Великий Бурлук’. Гіпотеза про розщеплення географічної назви на дві подібні за будовою топонімні одиниці не підтверджується, оскільки найперші писемні фіксації засвідчують розміщення поселення Середній Бурлук при річці Бурлук [АХН-1787]. Населений пункт, що має назву 3 демінутивною семантикою Середній Бурлучок [Хр Ввч, ХГ СНМ, с. 70], яка відома ще й як фонетичний варіант із аугментативним субстантивом Сродний Бурлук [Там само]. Відтінок збільшеності назви поселення Середній Бурлук співіснує з демінутивною варіантною ойконімною формою Картававий Бурлучок, с. [Хр Ввч, СКХЕ, с. 218], яка за морфологічним складом та звуковим вираженням близька до назви Картовий Бурлучок, сл. [Хр Ввч, СВСХГ, с. 15] спільної назви двох ойконімних об'єктів - села Середньобурлучанське Перше [Хр Ввч, СВСХГ, с. 15] та села Середньобурлучанське Друге [Там само]. Назва слободи Картавий Бурлук [Хр Ввч, КВУ-2], що трапляється в топонімічних джерелах поч. XIX ст. і яка за семантикою близька до попередньої та співзвучна 3 нею, стосується лише поселення Середній Бурлук. У такій ситуації можливі випадки не лише контактного перенесення й появи співвідносної пари або цілого ряду, але й дистантна взаємодія або навіть мотивація утворення групи ойконімів завдяки топонімному перенесенню, де впроваджується принцип бінарної опозиції за відношенням до розташування об'єкта 3 продукуючою назвою, його розміру та вікових особливостей. Якщо в джерелах XVIII ст. трапляються такі гідронімидемінутиви, як Середній Бурлучок, Сухий Бурлучок, Мокрий Бурлучок [Хр $\mathrm{Xp}, \mathrm{AXH-1787;} \mathrm{Хр} \mathrm{Чг,} \mathrm{ОХН,} \mathrm{с.} \mathrm{99],} \mathrm{що} \mathrm{можна} \mathrm{пояснити} \mathrm{впливом} \mathrm{гідроніма}$ Великий Бурлук, то в топонімічних документах XIX-XX ст. вони вже зафіксовані у вигляді аугментативів: Великий Бурлук, Середній Бурлук, Сухий Бурлук [Р. ПГОНО, с. 255-256]. Відомі випадки сер. XVIII - поч. ХІХ ст., 
коли назва річки існує без уточнюючого означення разом зі своїм ойконімним відповідником (р. Бурлук $\rightarrow$ сл. Бурлук [Хр Ввч, КСУГ-РА] та р. Бурулук $\rightarrow$ пос. Бурулук [Хр Ввч, КГ-АР]), де в останній парі назв розвинувся вставний звук [у], що зайняв позицію інтерфікса.

Формант -чок з'явився як засіб протиставлення омонімічних топонімів та як деривативний засіб, що виконує релятивну функцію або вказує на невеликі розміри географічної одиниці: село Середній Бурлучок - при річці Бурлучок [Хр Ввч, ИХХГ, с. 109; ОИКСОМГ, с. 553] (пор.: р. Сухий Бурлук [Р. ПГОНО, 256; КВУ-2] - р. Сухий Бурлучок [АХН-1787; ОХН, c. 99]). Семантичний зв'язок споріднених найменувань $є$ основним засобом, що сприяє подальшому розчленуванню вторинних структур з омонімічними показниками: пос. Середній Бурлучок [Хр Ввч, СМУВХГ, с. 97] - пос. Середній Бурлучок Перший [Хр Ввч, ССОВХГ, с. 96], пос. Середній Бурлучок [Хр Ввч, СМУВХГ, с. 97] - пос. Середній Бурлучок Другий [Хр Ввч, ССОВХГ, c. 96]. Наступним етапом номінаційного процесу $є$ двоосновне утворення на основі перших двох компонентів із збереженням числівникових параметрів: село Середньобурлучанське Перше [Хр Ввч, СВСХГ, с. 15] та село Середньобурлучанське Друге [Хр Ввч, СВСХГ, с. 15].

Інше тлумачення мотиву номінації власної назви - це поява поселення посередині між селищем Великий Бурлук і селом Нижній Бурлук. Для Нижнього і Середнього Бурлуків ойконім Великий Бурлук у цій топонімній ситуації є Верхнім, що засвідчено в одному із джерел (Верхній Бурулук, сл. [Аз Ввч, Кордт-ГКАзГ]). Демінутивне ойконімне словосполучення, протилежне Великому Бурлуку - це назва поселення Малий Бурлук [Хр Ввч, СМУВХГ, с. 96; Хр Вбрл, СЗПКО, с. 10] (вар. Малий Бурлучок, д. [Хр Ввч, СВСХГ, с. 11]), яке має географічну прив'язку до верхів'я річки Великий Бурлук і має семантику 'за розмірами $i$ за кількістю жителів поступається Великому Бурлуку', розглядається при цьому на рівні власне ойконімних смислових з'вязків або ж актуалізується ознакою 'мілководна частина річки Великий Бурлук’, виявляючись таким чином у комбінованому гідронімоойконімному системному ряді.

Формування четвертої групи власних назв, що має мотиваційний зв'язок топонімного об'єкта 'розміщений у нижній частині річки Великий Бурлук', пов'язана з наявністю ойконімних лексем, які вживаються з означенням нижній. Первинна ойконіма фіксація має аугментативну семантику, що виявляється в безафіксному утворенні (Нижній Бурлук, сл. [Хр Ввч, Кордт-КХН; ИСОХГ, с. 126], Бурлук Нижній, сл. [Хр Ввч, ХГ СНМ, с. 70]). Трапляються і демінутивні лексеми, які індивідуалізують різні типи поселень, як-от: Нижній Бурлучок, сл. [Хр Із, ОХН, с. 166, с. 167; Хр Ввч, СКХЕ, с. 206] та Нижній Бурлучок, с. [Хр Ввч, ОИКСОМГ, с. 553]. Суфіксальне ойконімне словосполучення стало словотвірною основою для появи ще двох демінутивних трикомпонентних структур із числівниковим значенням: Нижній Бурлучок 
Периий, с. [Хр Ввч, СВСХГ, с. 13; ССОВХГ, с. 97] (вар. Нижній Бурлук Перший, с. [Хр Вбрл, ПИПН, с. 24]) та Нижній Бурлучок Другий, с. [Хр Ввч, СВСХГ, с. 13] (вар. Нижній Бурлук Другий, с. [Хр Вбрл, ПИПН, с. 24]). Малоймовірно, що трислівні ойконіми-демінутиви в цьому разі утворилися не шляхом появи числівника, а на основі уже існуючих трислівних структур шляхом суфіксації, оскільки в більш ранніх джерелах (XVIII-XIX ст.) наведено приклади з суфіксальним оформленням, а безсуфіксні назви трапляються у списках 20-х pp. XX ст. Інші джерела вказують на те, що незважаючи на існування річки Середній Бурлук [КВУ_2] подібні назви поселень з'явилися в середній частині річки Великий Бурлук, про що засвідчує більшість писемних джерел (Середній Бурлук, с. [Хр Ввч, АСУГ; Хр Вбрл, АТП-46, с. 593], Середній Бурлук, х. [Хр Вбрл, СЗПКО, с. 10]). Не фіксують гідроніма Середній Бурлук і «Описи Харківського намісництва кінця XVIII ст.» та «Книга Большому Чертежу», де подано повний перелік великих і малих річкових об’єктів.

Деякі похідні ойконіми утворилися в результаті еліпсизації уточнюючого означення на базі гідронімного словосполучення (Великий Бурлук, p. $\rightarrow$ Бурлук, сл. [Хр Ввч, КСУГ-РА]), інколи - із суфіксацією (Великий Бурлук, р. $\rightarrow$ Бурлуцьке, сел. [Хр Чг, ХО. АТП-59, с. 42]). Ряд назв поселень стали результатом суфіксальної деривації (Бурлук р. $\rightarrow$ Бурлуцький, д. [Хр 3м, ХГ СНМ, с. 81], Бурлуцьке, с. [Хр Із, ХГ СНМ, с. 166]), частина з них утворилася в результаті основоскладання (Великий Бурлук, р. $\rightarrow$ Великобурлуцььке, сел. [Хр Вбрл, АТП-69, с. 414] або словоскладання (Великий Бурлук р. $\rightarrow$ Бурлуцький-Капустянський, х. [Хр Швч, ІМСУ ХО, с. 947]).

Входячи до топонімійної системи 3 антонімічними семантичними зв'язками рядності Великий - Малий, Новий - Малий - старий (=Великий), «Верхній (=Великий)» [Нерознак 1983, с. 125] - Середній - Нижній, ці квалітативно-квантитативні означення перебувають у різних парадигматичних відношеннях, що об'єднуються на основі протиставлення. Усі розрізнення назв поселень відбуваються винятково на основі допоміжних атрибутивних засобів.

Отже, етимологічний гідронім Бурлук (Великий Бурлук) в окремо взятому топонімному просторі Слобожанщини характеризується різнонаправленістю номінаційних процесів, значною активністю як у квантитативному смисловому плані, утворивши велику кількість похідних гідронімів і ойконімів, так і квалітативному, продукуючи різні за структурою і способом назвотворення та семантичним спектром топонімні лексеми.

а) джерела

\section{Умовні скорочення}

АСУГ - Атлас Слободской украинской губернии, сочинён по разделений оной вновь на десять уездов в 1802 году.

АТП-46 - Українська РСР : адмін.-терит. устрій на 1 вересня 1946 року. - К. : Укр. вид-во політ. літ-ри, 1947. - Вид. 1. - 1064 с.

АТП-69 - Українська РСР : адмін.-терит. поділ на 1 квітня 1967 року (3 додатком 
відомостей про зміни до 1 січня 1969 р.) : у 2-х т. - К. : Вид-во політ. літ-ри України, 1969. - Т. 1. -540 c.

АТУ-87 - Українська РСР : адмін.-терит. устрій на 1 січня 1987 року. - К. : Гол. ред. УРЕ, 1987. - 504 с.

АХН - Атлас Харьковского Наместничества 1787 г. с топографическим описанием. Посвящается Археологическому Съезду / Издание Харьк. Губ. Стат. Комитета под ред. В. В. Иванова. - Харьков, 1902.

ЗПХО - Залюднені пункти Харківської округи. - Харків : Держ. вид-во «Господарство України», 1930. - Вид. 2. - 96 с.

ИСОХГ - Пассек В. В. Историко-статистическое описание Харьковской губернии 1836 года / В. В. Пассек // Материалы для статистики Российской империи. - СПб. : В типографии министерства внутренних дел, 1839. - С. 125-167.

ИСОХЕ-4 - Историко-статистическое описание Харьковской епархии: уезды Змиевский и Волчанский / Д. Г. Филарет (Гумилевский). - Харьков : В Университетской типографии, 1857. - Отд. 4. - 336 с.

ИХХГ - Историческая хронология Харьковской губернии / Сост. К. П. Щелков. Харьков : Университская типография, 1882. - $461 \mathrm{c.}$

ІМСУ ХО - Харківська область // Історія міст і сіл УРСР : у 26-и т. / Голов. редкол. : П. Т. Тронько (голова) та ін. - К. : УРЕ АН УРСР, 1967. - 1003 с.

ICУ - Багалій Д. І. Історія Слобідської України / Д. І. Багалій. - Харків : Дельта, 1993. $-256 \mathrm{c.}$

КБЧ - Книга Большому чертежу / Под ред. К. Н. Сербиной. - М.-Л. : Изд-во АН CCCP, 1950. - $228 \mathrm{c}$.

КВУ-2 - Карта Волчанского уезда / Сост. А. Ф. Шелеспанов. - М 1:126 000. Х., (Б. г.).

КГ-АР - Карта Географическая, содержащая Смоленскую губернию с частями губерний Киевской, Белогородской и Воронежской (карта № 5) // Атлас Российский, состоящий из 19 специальных карт, представляющих всероссийскую имеприю с пограничными землями... съ приложенною притомъ Генеральною картою великия сея империи, старанием и трудами императорской АН, СПб., 1745.

Кордт-ГКАзГ - Кордт В. Матеріали до історії картографії України. Ч. 1. - К. : ВУАН, 1931. - XXXIX с., 41 к. // Генеральная карта Азовской губернии с ея уездами, сочинённая И. Исленевым, 1782 г. (Карта № 32).

Кордт-КХН - Кордт В. Матеріали до історії картографії України. Ч. 1. - К. : ВУАН, 1931. - XXXIX с., 41 к. // Карта Харьковского наместничества, (Карта № 38).

КСУГ-РА - Карта Слободской Украинской Губернии (карта № 36) // Российский атлас из 43 карт состоящий и на 41 губернию Империю разделяющий. Издан при Географическом департаменте, 1800 г.

ОИКСОМГ - Багалей Д.И. Очерки из истории колонизации степной окраины Московского государства / Д. И. Багалей. - М. : В Университетской типографии, 1887. - 614 с.

ОХН - Описи Харківського намісництва кінця XVIII ст. / упоряд. В. О. Пірко, О. І. Гуржій. - К. : Наук. думка, 1991. - 224 с.

ПИПН - Предварительные итоги переписи населения 1926 года по Купянскому округу. - Купянск : Тип. «Советская печать», 1927. - 55 с.

Р. ПГОНО - Россия. Полное географическое описание нашего Отечества: настольная и дорожная книга для русских людей / Под ред. В. П. Семенова. - СПб.: Издание А. Ф. Девриена, 1903. - Т. 7: Малороссия. - 517 с.

СВСХГ - Список волостей и селений Харьковской губернии. - Харьков : Издание Харьковской губернской земской управы, 1909. - 56 с.

СЗПКО - Список заселених пунктів Куп'янської округи 1925 року. - Куп'янськ : Друк. «Червоний друк», 1926. - 57 с.

СКХЕ - Справочная книга для Харьковской епархии / Сост. И. Самойлович. (c) Є. М. Ткаченко, 2013. 
Харьков : Типо-Литография И. М. Варшавчика, 1904. - 471 с.

СМУВХГ - Список мировых участков и волостей Харьковской губернии. Харьков : Тип. М. Гордона, 1873. - 114 с.

ССОВХГ - Список сельских общин и волостей на территории Харьковской губернии. - Харьков : Тип. М. Гордона, 1876. - 112 с.

ТКХО - Харьковская область: Топографическая карта. - К. : ВКФ ТСВС Украины, 1997. - М 1:200 000.

ХГ СНM - Списки населённых мест Российской империи. T. XLVI. Харьковская губерния. Список населённых мест по сведениям 1864 года. - СПб. : Издан ЦСК МВД, 1869. $-210 \mathrm{c}$.

ХО. АТП-59 - Харківська область : адмін.-терит. поділ на 1 грудня 1959 р. Довідник. - Харків : Книжкове вид-во, 1960. - 103 с.

\section{б) губернії / області}

Хр - Харківська

\section{в) повіти / райони}

Вбрл - Великобурлуцький, Ввч - Вовчанський, Зм - Зміївський, Із - Ізюмський, Пчн - Печенізький, Чг - Чугуївський, Швч - Шевченківський, Хр - Харківський

\section{г) інші скорочення}

д. - деревня, пос. - поселення, р. - річка, с. - село, сел. - селище, сл. - слобода, х. - хутір

\section{Література}

1. Григорян Э. А. Словарь местных географических терминов болгарского и македонского языков / Э. А. Григорян. - Ереван : Изд-во «Айстон», 1975. - 260 с.

2. Масенко Л. Т. Проблеми взаємодії гідронімії та ойконімії: на матеріалі басейну Південного Бугу / Л. Т. Масенко // Мовознавство. - 1972. - Вип. 1. - С. 32-37.

3. Михайличенко Н. Є. Взаємодія гідронімії та ойконімії (на матеріалі центрального та

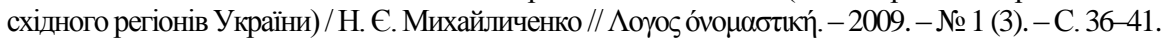

4. Нерознак В. П. Названия древнерусских городов / В. П. Нерознак. - М. : Наука, 1983. - 207 c.

5. Отин Е.С. О природе топонимического этимона / Е. С. Отин // Питання сучасної ономастики. - К. : Наук. думка, 1976. - С. 14-19.

6. Отин Е. С. Топонимическая метонимия: Вид связи «гидроним - ойконим» / Е. С. Отин // Перспективы развития славянской ономастики. - М. : МФГО СССР, 1980. - С. 106-121.

7. Отин Е. С. Структурно-семантические отношения в топонимических парах: гидронимаугментатив и гидроним-деминутив / Е. С. Отин // Русское языкознание: Республиканский межведомственный сборник / Е. С. Отин. - К. : Изд-во КГУ, 1989. - С. 124-129.

8. Отин Е. С. Ряжск или Рясск? / Е. С. Отин // Русская речь. - 1996. - № 2. - С. 84- 91.

9. Радлов В. В. Опыт словаря тюркских наречий: В 4-х т., 8-и кн. / В. В. Радлов М. : Изд-во вост. лит-ры, 1963. - Т. 4. - Ч. 2. - 1117 - 2230 ствб.

10. Топонімічний словник Харківщини / авт.-упоряд. А. М. Перепеча, А. П. Ярещенко; ХДНБ ім. В. Г. Короленка, ХДПІ ім. Г. С. Сковороди. -Х. : Б.в., 1991. - 117 с.

11. Фасмер М. Этимологический словарь русского языка : в 4-х т. / М. Фасмер. М. : Прогресс, 1986. - Т. 1. - 562 с.

12. Черняхивская Е. М. Взаимоотношения между названиями населенных мест и гидронимами / Е. М. Черняхивская // Доклады и сообщения Львовского отдела Географического общества УССР за 1964 год. - Львов, 1965. - С. 82-84.

13. Черняхівська С. М. Питання гідронімо-топонімічної метонімії // 3 Українська Республіканська ономастична (гідронімічна) конференція [тези] / Є. М. Черняхівська. К. : Наук. думка, 1965. - С. 91-95.

14. Юрків М. М Гідронімно-ойконімні паралелі в західноукраїнському ономастиконі : дис. ... канд. філол. наук : 10.02.01 / М. М. Юрків. - Тернопіль, 2000. - 244 с. 